\title{
Central Thai Food Culture and Acculturation During World War II and the Vietnam War
}

\author{
Ratiwan Watanasin (รติวัลย์ วัฒนสิน) \\ Assistant Professor in Marketing, Department of Marketing, Faculty of \\ Management Science, Suan Dusit University, Bangkok, Thailand \\ rwatanasin@yahoo.com
}

\begin{abstract}
As food has a substantial cultural and economic value, globalization and the Internet have posed challenges to traditional culture. As previous research on Thai food has focused on recipes and the consumption behavior of the royal family and upper-class Thai citizens, this study therefore aims to investigate the Thai food culture of ordinary Thais before the proliferation of a foreign food culture. Senior citizens from diverse socio-economic backgrounds in central Thailand who witnessed two major cultural encounters, specifically World War II and the Vietnam War, were interviewed until full data was obtained. Content analysis within the guidelines of consumer behavior analysis was conducted. The findings confirm that central food culture has been passed down over generations and has become firmly established. Unless there has been convenient access to provincial centers, then, food from other regions has seldom been consumed. Also, before globalization, acculturation with foreign foods was barely noticeable. Overall, a key driver of this acculturation was so-called "food availability".
\end{abstract}

\section{Keywords}

food culture - Thai food - food acculturation 
บทคัดย่อ

วัฒนธรรมอาหารไทยภาคกลางและการยอมรับวัฒนธรรมอาหารต่างชาติ ในช่วงสงคราม โลกครั้งที่ 2 และสงครามเวียดนาม

เนื่องจากอาหารมีคุณค่าทางวัฒนธรรมและทางเศรษฐกิจสูงมาก โลกาภิวัตน์และอินเตอร์เน็ตจึง ก่อให้เกิดความท้าทายต่อการเปลี่ยนแปลงของวัฒนธรรมดั้งเดิม งานวิจัยที่ผ่านมามุ่งเน้นการศึกษา ตำรับอาหารและพฤติกรรมการบริโภคของราชวงศ์และชนชั้นนำของประเทศ ดังนั้น การศึกษา ครั้งนี้จึงมุ่งที่จะค้นหาวัฒนธรรมอาหารของคนไทยทั่วไปก่อนการแพร่หลายของวัฒนธรรมอาหาร ต่างชาติ โดยการสัมภาษณ์ผู้สูงอายุที่มีสถานะทางสังคมเศรษฐกิจแตกต่างกันในภาคกลางจนได้รับ ข้อมูลครบถ้วน และวิเคราะห์เนื้อหาตามแนวทางของการวิเคราะห์พฤติกรรมผู้บริโภค ผลการวิจัย ยืนยันว่า วัฒนธรรมอาหารไทยสืบทอดกันมาจากรุ่นสู่รุ่นและหยั่งรากลึกในวัฒนธรรมไทย ถ้าการ เดินทางไปถึงศูนย์กลางของเมืองหรือจังหวัดไม่สะดวก โอกาสในการบริโภคอาหารจากต่างถิ่นจะ มีน้อยมาก ก่อนยุคโลกาภิวัตน์ การยอมรับอาหารต่างชาติแทบจะไม่สามารถสังเกตเห็นได้ สิ่ง สำคัญที่ส่งผลต่อการยอมรับวัฒนธรรมอาหารต่างชาติ คือการมีวางขายทั่วไป

\section{$1 \quad$ Introduction 1}

Food is a key element that can communicate cultural identity. Regional, local or traditional food is universally reflected as a treasure in the mindset of consumers and marketers. According to Tellström, Gustafsson, and Mossberg (2006), marketers often apply cultural heritage in the brand positioning of products to match consumer ideals. Repeatedly, and controversially, the terms "ancient recipe" and "royal cuisine" are applied in Thai food marketing for the purpose of creating awareness and an image of value. However, these terms create doubts among well-informed consumers because the expressions are vaguely defined and the origins of recipes can rarely be identified.

Since there are few ancient records regarding Thai food culture to determine its origin, together with evidence that foreign trade and relationships occurred over thousands of years in the region of today's Thailand (Vallibhotama 2011), understandably, it is extremely difficult to describe traditional and acculturated Thai food. Moreover, previous research on Thai food has mainly focused on recipes and consumption behavior of the royal family and upperclass Thai citizens. Therefore, the aim of this study is to investigate food culture in central Thailand by analyzing how central Thais defined their own cuisine and how they explained their consumption behavior and habits as well as that

1 This article is part of a research project entitled "Thai Food Culture: Food Consumption of Central Thais before 1955", funded by The Thailand Research Fund and Suan Dusit University. 
of people in their society. Since there were two major cultural interactions during World War II and the Vietnam War, it is important to examine the associated impact on central Thai food culture among ordinary Thai citizens.

\section{Literature Review}

There is culinary proof from the distant past, such as the journal of La Loubère (2009), the journal of Pallegoix (2011) or the cookbooks of Bhasakorawongse (2002), which explain cultural similarity in terms of cooking and consuming when traditional terms are compared with today's food culture. The Western authors were traders, diplomats or missionaries and recorded more about what was related to their duty than the food culture. Since those authors mainly worked in the capital cities of Ayutthaya and Bangkok, they mainly recorded central Thai food culture. Later on, the word "Thai" referred to central Thai. Their work is expressed in the following instances. La Loubère, a French diplomat during the reign of King Narai (1656-1688), extensively recorded facets of Siam (renamed Thailand in 1939) during his travels in 1687. Much of the food culture recorded by him is still widely practiced in modern times. For example, in those early days, Thais ate rice, fish, nam phrik (a type of Thai chili dip) and vegetables. Also, the similarity is in the way rice and fish were cooked, as well as how nam phrik was consumed. Bhasakorawongse (2002), an upper-class lady in Bangkok (1854-1911), published the first Siamese cookbook in 1902. She explained similar food items and also presented food from other regions of Siam, foreign ingredients and cross-cultural recipes. According to Sujachaya (2018b), during a ceremony at the Temple of the Emerald Buddha in 1809, common dishes such as nam phrik, chicken phanaeng (a type of curry), khanomcin namya (rice noodles with curry) and khaoniao kaeo (crystallized sticky rice) were served to monks. There were also foreign-styled food, such as rice cooked with spices from Middle-Eastern culture and glassnoodle soup from China. Even though there is no solid proof, Sujachaya (2018b) believes that those foods are in the continuum of Ayutthaya cuisine, presenting as circumstantial evidence the fact that some court ladies in the Thonburi kingdom (1767-1782) and during the reign of Kings Rama I and II (1782-1824) were upper-class women from Ayutthaya. Thus, many Thai recipes are considered to be ancient.

Central Thai Food Culture From a record during the period included in this study (Phya Anuman Rajadhon, 1956), Thailand was divided into four regions, these being the northern, north-eastern, central and southern regions, and the cultures of the four regions overlapped with one another. Also, because of 
the wealth and fertility of the Ayutthaya Kingdom (Sujachaya 2018a), people from other countries were eager to visit and trade. In fact, as Vallibhotama (2011) describes, even before the Ayutthaya period, due to the accessibility of Siam and earlier kingdoms, there were a series of migrations and political relationships, as well as commercial and cultural exchanges, with other ethnic groups and countries. Nonetheless, Sujachaya (2018b) believes that historical evidence of Siamese food culture is scarce. For instance, little evidence is available in the royal orders and literature of the early Rattanakosin period, which often describe only lists of dishes instead of how foods were cooked, served and consumed. Still, one of the best descriptions of local consumption behavior is in Sepha Khun Chang Khun Phaen, a Thai epic poem compiled by King Rama II et al., (2003) during the era of King Rama II (1767-1824).

In relation to this, Central Thailand is pertinent with its vast lowland plain and a major river system that flows through Phitsanulok, Ayutthaya and Bangkok, and into the Gulf of Thailand. Comparable with the work of La Loubère (2009), Pallegoix (2011) first visited Siam in 1830, stayed for 24 years and recorded that Siam was abundant with natural resources, with rice and fish being central to Siamese food culture. These foodstuffs symbolized prosperity and well-being, which is clearly reflected in conversation, proverbs and rituals. For example, the greeting, "Have you eaten rice yet?", in Thai, is equivalent to "How are you?" Generally, daily meals in the olden days were very modest. From a record in the 19th century described by Reid (1988), the height of Siamese people at the time was $5^{\prime} 1^{\prime \prime}$ for males and 4'11" for females. Probably, this was because they consumed a small amount of meat but, as reported, were very healthy.

Typically, cuisine is an artifact of local abundance and socio-cultural prosperity. According to Sujachaya (2018a, 2018b), from the Ayutthaya to the early Rattanakosin periods (1350-1932), except for the wartime periods, natural food was abundant and food was inexpensive and Siamese meals were simple. The staple diet was rice with side dishes such as fish, nam phrik, curry and vegetables. By comparison, food was extravagant during ceremonies or at festive events. In addition to royal orders and literature, early records of Thai food come from reports by foreigners and Kasempholkoon (2018) indicates that those records only explain the broad concept of food culture and consumption behavior. They do not explain the food items in details.

As stated by Kasempholkoon (2018), royal cuisine was similar to food at home but it was carefully prepared, decorated and served. During the reign of King Rama v, a meal for the royal family, consisted of seven kinds of food, such as rice, a meat dish, curry, a Muslim dish, a dipping sauce, soup and a dessert. Many kinds of dishes were devised by ladies of the court, and some of these were adapted from other regional and foreign foods. Through the families of 
court ladies, royal cuisine was transferred to common households and businesses. Also, he explains that royal recipes were passed down verbally. To prevent the loss of Siamese cuisine, written recipes and published cookbooks were promoted. Moreover, cookbooks such as Bhasakorawongse's, were used as a representation of civilized Siamese culture to prevent colonialism by Western countries. The cookbook's popularity started with the court ladies and upper-class women. Thanks to international relationships, culinary activities in palaces and the establishment of girls' schools, Thai cuisine was greatly expanded and elaborated. According to Jenjad (2013), after the revolution that ended absolute monarchy, in 1932, the members of the royal family became scattered. Even so, there were activities to preserve the royal cuisine and culinary knowledge. Many new or edited cookbooks of royal families were published and some of these were added to curricula in schools and colleges. Several were highly promoted through the growth of mass media.

In the book "Flavorful Dishes from Grandparents: 100 year-old Recipes" (Wongwongsi 2014), recipes from 15 families are presented together with interviews of recipe owners who were mostly senior citizens living in Bangkok. One of the interviewees who learned cooking from a very young age tells how, in the olden days, there were not as many restaurants and processed foods, such as preserved curry paste or coconut milk. Ingredients, such as vegetables, banana and mango came from the back yard and fish sometimes came from nearby canals. Food had to be cooked in the kitchen by the woman of the house with her children as assistants. Moreover, some recipes came from other cultures. For instance, a rice dish from a Bunnag family was of Persian origin or another rice dish originated from southern China.

Food Acculturation According to Berry (2008), acculturation is a process of cultural change after both (or all) groups of different cultures have been in contact. As Gabaccia (1998) has said, food symbolizes national or ethnic history and traditions and it evidently marks cultural values and traits. Naturally, consumers eat their native food because of its familiarity and availability. If they migrate, immigrants inevitably consume local food but she believes, where possible, they will consume their native food with the intention of preserving their ethnic values and group membership. Given that globalization, international tourism and the Internet have increased food familiarity, availability and the chance to try foreign foods, it is highly likely that consumers will eventually acculturate preferable parts of the new culture and make these parts their permanent culture. Gabaccia (1998) explains that the leading reasons for acculturation are because it involves pleasure seeking, economic gain, as well as being a reflection of consumer preferences by being cosmopolitan or globalized. 
Lund and Manyika (2016) find that the Internet not only offers opportunities in the international marketplace but also increases its complexity. Tsunamis of data flowing across borders are transforming globalization by speeding up nascent changes in the value chain, altering consumer behavior and increasing the competitive environment. In addition, the Internet, travelling abroad and the physical flow of products and services are also transforming the marketplace. Thais who had personal encounters with them unquestionably accepted part of foreign cultures. Berry (2005) warns that acculturation may offer a better understanding of other cultures but it also proposes cultural conflicts. For example, there is an increasing threat of obesity due to the consumption of foreign fast food and processed food. Nowadays, the influx of new foods has transformed the Thai food landscape faster and very obviously. The changes have been in terms of form and values that, to some extent, have altered the understanding of Thais with regard to their own food culture. Since traditional food is often interpreted as a desirable premium product (Tellström et al. 2006), the increasing risk of losing associated cultural elements has prompted Thai academia to research and promote genuine cultures.

Berry (2009) states that acculturation simply mean taking on another culture. As is apparent, the process of acculturation begins when people of different cultures engage and exchange their values, beliefs, socio-cultural knowledge and consumption preferences. Earlier acculturation research focused on a unidirectional process; specifically, the immigrants' acculturation of the host culture (Ownbey and Horridge 1997; Penaloza 1994). Subsequent works have applied Berry's bidirectional model; that is, the acculturation happens in both the culture of the newcomer and in the culture of the host. Still, a plethora of research has reported acculturation in immigrant populations (Franzen and Smith 2009; Hartwell, Edwards, and Brown 2011; O'Sullivan and Amirabdollahian 2016; Vargas and Jurado 2016). By comparison, much less research has explained acculturation in the host culture (Dinh and Bond 2008; Sapienza, Hichy, Guarnera, and Di Nuovo 2010). In truth, Ben-Shalom and Horenczyk (2003) have indicated that since no one has absolute cultural resistance, especially during prolonged social interaction, either the guest or host cultures can be acculturated. Also, Tseng and Yoshikawa (2008) found that much of acculturation research tends to be more interested in the effects on individuals, rather than upon any cultural structure. To sum up, this study tries to explain how intercultural contacts collectively influenced cuisine and food habits in central Thailand.

For historical evidence of acculturation in Siam and Thailand, La Loubère (2009) was served with a variety of ethnic foods at envoy receptions in 1687. Some of the dishes were imported directly from other countries or cooked by 
foreign chefs working in the royal palace. Pallegoix (2011) described a list of imported foods, such as tea leaves, wheat flour, cinnamon, cloves, beer, wine, brandy, pickled garlic and fruits. As Sujachaya (2018b) has described, Sir John Bowring, the English diplomat who dined with King Pinklao, the "second king" in the reign of King Rama IV, in 1855, also described mixed ethnic foods served in a Western-style setting. This setting indicated a deeper level of acculturation since the Siamese sat on the floor while dining and ate by hand. For evidence of acculturation for the general public, a description of the Ayutthaya landscape during the King Narai period (Pongsripian 2008) shows lists of local markets specializing in fresh and cooked foreign foods. Some ethnic items, such as curry, stir-fried dishes, noodles, soy sauce and desserts made from eggs have become permanent elements of Thai food culture.

As well as the work of la Loubère in 1687, Pallegoix in 1854 and Bhasakorawongse in 1902, which provided valuable details of ancient food culture and acculturation, there is a famous poem by King Rama II (1767-1824) (Na Songkla 1982), which elaborates on the contents of his queen's menu. The King cites central and regional dishes, local ingredients, Indian bread and spices, Japanese soy sauce and imported fruit from China. Some of these, both Thai and acculturated foods, are consumed commonly nowadays. Except for phat thai, the history of well-known acculturated dishes, such as khanomcin, sate and green curry is unclear. Greeley (2009) wrote that phat thai was invented during the Second World War. According to Prince Wan Waithayakon (1944), the Prime Minister at that time, Field Marshal Plaek Phibunsongkhram, was promoting Ratthaniyom or state custom and convention, to encourage the spirit of united patriotic action for the greatness and prosperity of Thailand. In line with a policy to solve severe food shortages, Thai citizens were encouraged to grow their own produce, raise cows, pigs and chickens, and sell them. Also, Phat Thai, as a fried noodle dish that originated from Chinese food, was invented to promote nutritional food with carbohydrate from noodles, protein from meat and eggs and vitamins from vegetables. The word "Thai" was added to promote Ratthaniyom. Muksong (2016) believes the aforementioned agricultural policy which promoted healthy ingredients is a key driver for Thailand to become a leading global food producer.

The qualitative marketing research underlying this paper provides an overview of traditional and acculturated Thai food culture from the perspectives of senior citizens in central Thailand who grew up before the proliferation of 
foreign food cultures. Also, they witnessed two major cultural encounters, these being the Second World War and the Vietnam War. This historical research applies a phenomenology concept with the purpose of using consumers' own and shared experiences to compare central Thai food culture before the two wars with that of later years. Since marketers have to create the right strategies to satisfy consumers, the concept of consumer behavior (Pride and Ferrell 2016) was applied in designing interview questions and as a guideline for data analysis. Food marketers, thus, have had to analyze what consumers eat to understand their preferences; why they eat what they eat, so that the marketer can prepare valuable offers; how and where they acquire, store, cook, consume and dispose of food; who participates in the consumption process and on what occasion or when the food consumption process occurs.

After a preliminary contextual study, early respondents were recommended by culinary and anthropological experts. The rest of the respondents were selected by means of their importance, recommendation, theoretical sampling and so-called snowballing. Initially, the researcher planned to have in-depth interviews with 15 respondents in each province but 89 interviews were conducted until the data became saturated. The interview period was from October 2014 to January 2016. Rich knowledge was derived from the content analysis of interviews with seniors and experts, who were mostly over 70 years old, and born and raised in the five focal provinces: Bangkok, Ayutthaya, Phetchaburi, Phitsanulok and Nakhon Sawan. Capitals and large provinces were chosen because consumers in those places had greater opportunities to experience a variety of food products. Moreover, since ancient times, Bangkok, Ayutthaya, Phetchaburi and Phitsanulok have been culturally, politically and financially significant, and these provinces have portrayed the intermingling of local and national cultures. Note that Phitsanulok can be considered either as a northern or a central province. The findings confirmed that its food culture was largely similar to the central region of Thailand. Takhli in Nakhon Sawan was added later because an American Air Force base was located there during the Vietnam War.

The research limitation was that adults who had intercultural experiences during the Second World War and the Vietnam War had already passed away or they were difficult to find. Since the respondents were questioned about incidents that happened $50-60$ years ago, while they were children or young adults, it was possible that their memories were blurry. None of them could provide photographs of culinary and intercultural experiences. Physical evidence, such as utensils, dishes and cutlery, had disappeared due to the passing of time and because of the relocation of the respondents. With the purpose of helping the respondents explain their food experiences, they were asked to compare 
the food that their parents had prepared for them and the food they had had when they were young adults, with what they had eaten recently.

The great advantage and hindrance of the data collection associated with this paper were to do with cooking and direct experiences. It was noticeable that the respondents who had extensive knowledge and experience in cooking could easily recall historic incidents. These respondents were around 70 years old, mostly with good memories, and they contributed enough data for analysis. For older respondents whose memories were fuzzier, their stories were valuable as well. They provided good evidence of cultural transition. Very few respondents recalled food-related incidents during the wars and no one outside Takhli had direct interactions with American air force personnel. In spite of the aforementioned obstacles, all the interviews went smoothly because consumption experiences occurred repeatedly and were considered to be the cause of happy memories.

The study underlying this paper follows the guidelines of consumer behavior analysis. The findings are organized into three groups: 1) central Thai food which explains food in the past and preferences 2) consumption process which explains food acquisition, preparation and consumption, and 3) food acculturation during the Second World War and the Vietnam War.

\subsection{Central Thai Food}

The findings reveal that Thai food was passed down through generations. All of the respondents interviewed admitted that foods in the past and present were similar in terms of type and flavor. The differences were in terms of the number of natural and processed ingredients, in addition to the availability of packaged food, restaurants and foreign products, the frequency of food preparation and the threat of chemicals in food. Food variation was mostly in the form of seasonal ingredients or new ingredients from other regions of Thailand, rather than anything coming from foreign countries. Unless there was convenient access to provincial centers, food from other regions was seldom consumed.

There are some distinctive collective food preferences over time since the respondents were young, and these are as follows:

Rice Consuming rice was very important. It was very fulfilling to consume high quality rice. Rice quality was determined by the grain, not by the type. Jasmine rice and the concept of healthy brown rice was yet 
recognized. White rice was common and preferred. Unlike in northern and north-eastern (Isan) Thailand, glutinous rice was not a daily staple. Some central farmers planted glutinous rice in a small part of their paddy field and, normally, it was used in dessert making. Some respondents believed rice in the past had a better flavor and more nutrients because it was grown only once a year and yearly flooding brought natural fertilizer to the fields. Rice and vegetables grew naturally. According to respondents whose parents were farmers, it was said that their parents did not need to buy chemical fertilizers, and that they used less pesticide.

Fish By the end of any rainy season, the water level was high and there were abundant freshwater fish. Thus, fish was the main source of protein. It was sun-dried, smoked, salted and fermented. The common fish menu item was grilled or boiled. Since cooking oil was needed, fried food was less convenient for families that did not live near markets. Pla ra (fermented fish) was rarely promoted as a food in the central area, although it was easy to find evidence of it, such as the pots for storing Pla ra in many rural households.

Nam phrik (chili dip) and pla thu (chub mackerel) Nam phrik or nam phrik and pla thu were favorite side dishes. Central consumers commonly ate fresh water fish. Pla thu, a marine fish, was the exception. Consumers could buy pla thu at a market or from mobile vendors. Some families made kapi (shrimp paste) for nam phrik from shrimp that they had caught during flooding season. Evidently, nam phrik and pla thu were regular menu items since the Ayutthaya period (Samattiya 2002).

Chicken and Pork The respondents' families cooked more pork than chicken because they could buy small pieces of pork. They also bought lard to make cooking oil. Chicken was more expensive because a whole or half chicken was the standard portion for sale.

Kaeng phet (curry) and Coconut The most common type of curry was kaeng som (sour curry) because it was very easy to cook. This dish consists of curry paste, meat, vegetables and the juice of sour fruits such as lime and tamarind. The respondents also cooked kaeng kathi (curry with coconut milk). They were not afraid of consuming fat but cooking with coconut was less convenient since many households did not grow coconut trees. Moreover, some types of kaeng kathi required more herbs and spices for the curry paste and also required more time to prepare. For example, matsaman curry was served on special occasions. 
Tom cuet, tom khem and tom yam These were three common types of soup with a mild, salted and spicy flavor, respectively. Tom cuet (mild soup) was a common menu item for children. Tom khem (soup with a stronger flavor than tom cuet) was the most common type of soup. Tom khem could be cooked quickly or simmered for a longer duration until the meat was tender. Chili could be added but it did not have a distinctive sour flavor like tom yam (hot and spicy soup).

Kuaytiao (noodle soup). Noodle soup was consumed more than stir-fried noodles. There were two common styles: Tom cuet (mild) and tom yam (spicy). The related ingredients were usually minced and sliced pork, rice noodles and vegetables. At one time it was a happy food that consumers sometimes ate with rice.

Somtam (papaya salad). Somtam in the central area was not popular and different from Isan somtam (northeastern-styled papaya salad) in terms of flavor, if a side dish, and in meaning. It was sweeter, consumed occasionally as a snack and was served alone or with coconut rice. Isan somtam was consumed as a part of the daily meal with glutinous rice and other meat or vegetable dishes. Central households grew papaya trees. The fruit was more often used for making curry and stir-fried papaya.

Vegetables The respondents felt that the natural environment was cleaner since, nowadays, there is pollution from cars, factories and the usage of chemicals. When respondents were young, they felt safer when picking vegetables from the wild. Moreover, the type and number of wild vegetables and fruits reduced rapidly because wild areas were transformed into cities. All the land had owners. So, they could not trespass on the land.

Fruit The most common fruit was banana. Many families grew banana trees. Banana could be eaten fresh or cooked as food and as a dessert. It was cheap or free so that it was marketed as poor-peoples' food. Sometimes, poor students who normally skipped lunch and came home to have dinner, ate only bananas at lunch time. Grilled bananas were popular, even among American soldiers.

\subsection{Consumption Process}

Consumption Process refers to consecutive activities occurring before and during food intake which include food acquisition (which refers to growing, finding, and buying food), food preparation (which refers to cooking) and food consumption (which refers to what, when, where and how Thais eat). 
Food Acquisition Typically, consumers who owned even a small piece of land normally grew some produce and fruit trees. Some educated respondents still recalled Premier Phibunsongkhram's food policy of "growing your own food". Consumers in rural areas, mostly being farmers, grew rice, beans, sugarcane, vegetables and fruit trees. Also, they acquired food from rivers and forests, exchanged products with neighbors or visited markets in district or provincial centers. The latter situation rarely occurred for those who lived far away from waterways or roadways because they had to walk for hours to a canal or river, had to pay for a boat ride to reach big markets or had to wait for buses that only came a few times a day. Some people raised poultry for eggs, as well as pigs and cattle for sale. Slaughtering farm animals for meat or consuming wild animals was rare. Making basic ingredients, such as sugar, fish sauce and cooking oil, was more common in rural areas. These production processes revealed part of the reason why rural respondents did not frequently cook fried food or make desserts.

Urban consumers conveniently bought ingredients, as well as prepared and processed food, from markets, stores or vendors who were peddling their wares along the streets. Also, consumers in Bangkok could take a tram to buy Chinese products from Yaowarat (the Chinatown of Bangkok) or buy a variety of products from Talat Yot (a large market) in Bang Lamphu (a business area near the Grand Palace) or try good dishes at Talat Nang Leong (a large market). Talat nat (temporary market) and mobile vendors have been crucial to central Thai food system where there were few shops and markets and consumers were eager to travel to nat or talat nat. They were sources of fresh food, prepared food and desserts. Farmers and vendors came to sell their products on a specific day of the week or month. Talat nat were usually located at a temple by a canal or river. Mobile vendors might go on foot, via a boat or a train. Products were sold along the way, in a market or around crowded areas. Noticeably in Bangkok and provincial centers, there were first- and second-generation Chinese who sold Thai food, such as rice, curry and sweets. Interestingly, the flavor and quality were at the same level as those of Thais. Boat peddlers could travel ten kilometers a day and reach remote areas via an intricate canal system. Although food logistics were limited, during annual festivals at major temples there were foods from various parts of Thailand.

During such festive events or in front of theaters, there were always food vendors. Since the respondents were young at that time, they did not have pocket money and, usually, they ate at home before going to these events. If the events were in distant places, they usually brought food from home. Thus, buying prepared food or dining in restaurants was rare. The main reasons were 
unavailability, lack of money and the preferred habit of eating at home. Even in Bangkok, the older that the respondents were, the rarer was the chance for them to have prepared or restaurant food in their youth. The opportunities to do so increased after there were more stores and restaurants, as well as when a widespread transportation system became available.

Food Preparation The numbers of extended family members reduced. Many respondents did not live with their grandparents. The main part of food culture, thus, was passed down to respondents from their ancestors through their parents. Still, they could acquire more knowledge and skills from grandparents during their visits and from acquaintances during local activities, which took place recurrently at their religion premises and where members of the local community shared information about their food or cooking activities. Therefore, the form and flavor of Thai food could be preserved from generation to generation. Normally, food was cooked by their parents, grandparents, older siblings or relatives, and it was consumed at home. Cooking skills were not taught or forced to be learned, but rather, these were acquired while observing them when underway.

Thai food culture was governed by women because the mother or woman of the house held the power to direct the culture. Women were assumed to take the role of food preparers. In fact, the actual role was fairly flexible. It was not age- or gender-oriented but was determined by household duty and the availability of time. Girls were not forced to cook, though they naturally helped their mothers in the kitchen. They could play around, or were assigned to take care of younger siblings or farm animals, as well as do gardening. Some girls or boys were in charge of cooking from a young age because their parents started working very early in the day. They cooked and, sometimes, delivered food to their parents at the workplace. It was noticeable that in the families where parents were not active in cooking, the meals were very simple.

During festivals and local activities, cooking for events was a major and conscientious duty. Ingredients were prepared by the host or voluntarily contributed by local members. Each dish was cooked by experts. These events offered good opportunities to try new foods, show expertise and learn good recipes. Unfortunately, this communal cooking activity is nearly extinct. Now, food for events is usually bought from stores or arranged by caterers.

The respondents reported that cooking activities were reduced and the chance to try new foods was higher as they got older since there were more processed and restaurant foods available, together with foods from different regions or countries. 
Food Consumption Whether urban or rural, rich or poor, meals were similar in terms of items and flavor. The disparity of food choices was due to family or local preferences. Usually, the menu was modest, with rice as the focal food, along with two to four side dishes. The number of meals was similar to nowadays. Several respondents were very poor but they rarely had to skip a meal because natural resources were abundant. They could find free ingredients in many places. In most respondents' families, consumption hours were flexible and no one forced to have meals together. Their parents gave a higher priority to daily duty. Thus, food was always available in the kitchen or it was carried or delivered to the workplace.

More elaborate kinds of food, snacks and dessert were provided during cerebrations, festivals or local community activities. Children had to accept whatever their parents or grandparents provided. They rarely demanded their favorites. Any forms of food allergy in children were not reported. Consuming snacks or desserts was infrequent but children felt no great pressure from the lack of them. The chance for children to try new foods arose during journeys or festive events. Also, they might receive them as gifts from adults who travelled to provincial centers or Bangkok. Mostly, the respondents who had wealthy, high-educated, or socially-active parents reported more kinds of foreign food items.

There were no concepts of cholesterol, vitamin supplements, weight control products or health products. Choice differences derived from the consumer's ability to travel and reach bigger markets. Most respondents grew up with very few, or no, foreign foods. They were typically attached to Thai flavors to the extent that some of them entirely rejected foreign foods. However, the concept of foreign food was individually variable. For example, they usually accepted bread and condensed milk, but they refused fresh milk and butter. In contrast, their grandchildren grew up observing various food cultures so they enjoyed Japanese food and American fast food. The respondents believed that modern food was of lower quality and unsafe. Purportedly, it contained fewer natural ingredients and contained more synthetic additives and preservatives. Regrettably, they yielded to a convenient lifestyle and chose to consume processed, restaurant and street foods.

\subsection{Food Acculturation}

Acculturated foods mentioned in ancient records, such as curry and noodles, were commonly cooked, consumed and commercialized. These foodstuffs were considered to be Thai food because they had a Thai flavor and had been eaten since the time when the respondents were young. They accepted Chinese food because of its familiarity but most respondents disliked Western or Indian food. Outside Bangkok, these types of food had not been available when 
they were young, while they were working adults or even during the influx of foreign tourists in 1980s. Extensive food acculturation occurred only with the proliferation of modern retailing in the 1990s. Department stores provided convenient access to foreign foods. The foods were often introduced by their grandchildren and not their children. However, they adopted very few kinds of so-called new food. In fact, friends in college and universities, as well as coworkers, had more influences than family members.

During the Second World War, the observed incidents mainly were not foodoriented. The most recalled memories were the fears prompted by aircraft, bombs, sirens and shelters. There were distant observations of when Japanese soldiers procured Thai food products. Direct contact was rare and there were no food-related items acquired from the Japanese. Partly because of the panic and concern of parents, children were kept indoors or were sent away. Evidence of acculturation from Japanese culture in this period was not found.

During the Vietnam War, only the respondents in Takhli, Nakhon Sawan, had direct contact with American soldiers whose operations in Thailand were limited and tightly controlled. American products were procured by the American government to accommodate the personnel, and these items were sold inside the base. They were unavailable to Thai citizens, except through personal relationships. During that period (1961-1976), there were restaurants serving American or Western food but it was not popular among Thai consumers because most of them did not enjoy the flavor. Also, some female consumers were uncomfortable being near American soldiers. Thus, acculturation from American food culture was minimal. The first bakery shop in Takhli was opened almost 30 years later. During the war, bread and bakery products were brought to the base from Bangkok. Normally, American soldiers had their meals at the cafeteria in the Air Force base before coming outside for entertainment. They tried Thai food, snacks and sweets while with their Thai partners or while traveling around Takhli's business area. There were also some adapted Thai foods, such as fried rice, at the cafeteria. It appeared that the Americans were more acculturated with Thai food during the time they spent in Takhli. Interestingly, the highest growth in the food business was other regional foods, such as Isan food. These were catered to serve the influx of laborers and sex workers.

With respect to food preferences, common foods, such as rice, dried fish, nam phrik, curry, tom yam, tom cuet, khanomcin or noodle soup, and cooking techniques, such as boiling, steaming, grilling or frying, have been in central food 
culture for a very long time. The past forms and flavors are parallel to those in the current period. If any variations exist, these were derived from new ingredients and seasonings from other parts of Thailand, rather than foreign countries. Part of the findings are thus comparable to what was reported by La Loubère in the $17^{\text {th }}$ century, and by Pallegoix in the $19^{\text {th }}$ century. Below are samples of the similarity to today's foods, which indicate the continuity of central food culture:

(1) Siamese meals are very modest. Main menus are rice and fish.... They prefer dried to fresh fish. Pla ra is also preferred. ... They like dipping sauce made from kapi (La Loubère 2009, 119-121).

(2) The Siamese common meal consists of rice, fish and vegetables. There is no bread because it is not suitable for a hot country. Chinese and affluent Siamese widely consume pork.... Country folks' meals are very modest. They eat rice, dried fish, banana, bamboo shoot and vegetables with a special spicy sauce called 'nam phrik'.. It is eaten by everyone, from the King to the poorest slaves (Pallegoix 2011, 145).

(3) There are several kinds of rice. Rice is cooked in a pot. After the rice is boiled, the water will be drained off and the rice cooked on low heat until it is fully cooked. Thais eat rice with curry, instead of bread. ... They do not eat sticky rice. They use it for making desserts (Pallegoix 2011, 96).

(4) Siamese like eating fruit more than anything. I only recognized oranges, citrus fruits and pomegranate. Banana can be found in every season (La Loubère 2009, 82-83).

(5) The most important and cheapest fruit is the banana (Pallegoix 2011, 104).

(6) During reception, I was served with 30 kinds of Chinese foods (La Loubère 2009, 125).

(7) There are two types of side dishes: Chinese and Thai foods (Pallegoix 2011, 146).

As for consumption process, Central Thai food culture evidently was a feminine culture. Typically, the mother or women in a family decided on the menu, the meal time and cooking techniques. The family with a full-time working mother was inclined to have simple meals and limited cooking skills. Food acquisition largely came from natural sources and local markets. Specialty and foreign items were available in provincial centers or Bangkok but in limited areas. Interestingly, food acquisition and preparation were not woman-only chores. The people were more flexible and were controlled by daily duties. 
Consumption activities mainly occurred at home, due to habit and the behavioral preference for consuming at home and older generations reported less experience of restaurants. However, urban consumers who were highly educated and socially active reported more opportunities and willingness to adopt new cultures. In recent years, home cooking has sharply reduced while consumption at restaurant, together with opportunities to consume foreign foods, is on the rise.

Acculturation emphasizes the direct interaction between different cultures (Berry 2009). Thus far, for food acculturation, if not more than that, the availability of foreign foods and restaurants is as crucial as direct interaction (Watanasin 2012). The age of consumers also determines the degree of acculturation. When the respondents were young, their consumption was tightly controlled by their parents. They had less to no chance to observe other cultures. In that way, they attached naturally to their native food and direct interactions at an older age might not have encouraged them to try new cultures unless the food had a high level of familiarity and the flavor fitted their palate. The main reasons that the entrance and diffusion of new food cultures was curtailed were its high cost and a partial logistics system, which led to unavailability of food, as well as reducing the chance for consumers to experience new food.

Acculturated foods mentioned in the historical documents from the Ayutthaya and early Rattanakosin periods were considered Thai food and became a permanent and proud part of Thai culture. In this research, acculturation during World War II and the Vietnam War was barely visible. During the Second World War, the respondents were too young, and they had no opportunity to closely observe the Japanese culture. In comparison, during the Vietnam War the controlled environment allowed a very limited group of consumers to acculturate the American culture. In fact, stated Western foods, such as bread, milk, butter, steak or burgers were already adopted in Thailand, though they were only accessible in limited societies.

\section{References}

Ben-Shalom, Uzi, and Gabriel Horenczyk. 2003. "Acculturation Orientations." Journal of Cross-Cultural Psychology 34 (2): 176-188.

Berry, John W. 2005. "Acculturation: Living Successfully in Two Cultures." International Journal of Intercultural Relations 29 (6): 697-712.

Berry, John W. 2009. "A Critique of Critical Acculturation." International Journal of Intercultural Relations 33 (5): 361-371. 
Bhasakorawongse, Plian. 2002. Maekhrua Hua pa (Chef). Bangkok: Cultural Associations. (In Thai).

Dinh, Khanh T., and Meg A. Bond. 2008. "The Other Side of Acculturation: Changes among Host Individuals and Communities in Their Adaptation to Immigrant Populations." American Journal of Community Psychology 42 (3-4): 283-285.

Franzen, Lisa, and Chery Smith. 2009. "Acculturation and Environmental Change Impacts Dietary Habits Among Adult Hmong." Appetite $5^{2}$ (1): 173-183.

Gabaccia, Donna R. 1998. We Are What We Eat: Ethnic Food and the Making of Americans. USA: Harvard University Press.

Greeley, Alexandra. 2009. "Finding Pad Thai." Gastronomica: The Journal of Food and Culture $9(1): 78-82$.

Hartwell, Heather J., et al. 2011. "Acculturation and Food Habits: Lessons to be Learned." British Food Journal 113 (11): 1393-1405.

Jenjad, Rattikarn. 2013. "Kan suesan kap Ahan (Communication and Food)." In Suesan Ahan Sukkhaphap (Communication, Food, Health), 8-139. Bangkok: Pappim. (In Thai)

Kasempholkoon, Apilak. 2018. "Origin and Development of "Royal Cookbooks" from the Age of King Rama v to the Establishment of Girl School." In Thai Gastronomy: From Home Kitchen to Royal Cuisine, edited by Sukanya Sujachaya, 221-252. Bangkok: Samlada.

King Rama II, et al. 2003. Khun Chang Khun Phaen Book 1-3. Bangkok: Teachers' Council of Thailand.

La Loubère, Simon de. 2009. Du Royaume de Siam. Translated by S. T. Komonlabut. Bangkok: Sripanya. (In Thai).

Lund, Susan, and James Manyika. 2016. How Digital Trade is Transforming Globalisation. Geneva: International Centre for Trade and Sustainable Development (ICTSD) and World Economic Forum. www.e15initiative.org/.

Muksong, Chatchai. 2016. "Pakthong yam songkhramlok khrang thi 2 kan ronnarong tham suankhrua lae liangsat kap cut phalik phan nai nayobai ahankankin khong rat thai (Consumption during wwir: The 'Home Gardening and Animal Husbandry' Campaign and the Turning Point of the Thai Government Food Policy)." Thammasat Archives Bulletin 19 (June 2015-May 2016): 59-69. (In Thai).

Na Songkla, Wandee. 1982. Royal Thai Cuisine Book ı. Bangkok: Ponpant Publishing. (In Thai).

O'Sullivan, Novella, and Farzad Amirabdollahian. 2016. "Loyal Tongue, Liberal Mind: International Students' Experiences on Dietary Acculturation in England." Journal of International Students 6 (1): 107-127.

Ownbey, Shiretta F., and Patricia E. Horridge. 1997. "Acculturation Levels and Shopping Orientations of Asian-American Consumers." Psychology \& Marketing 14 (1): 1-18. 
Pallegoix, Jean-Batiste. 2011. Description du Royaume Thai ou Siam. Translated by S. T. Komonlabut. Bangkok: Sripanya. (In Thai).

Penaloza, Lisa. 1994. "A Critical Ethnographic Exploration of the Consumer Acculturation of Mexican Immigrants." Journal of Consumer Research 21 (1): 32-54.

Phya Anuman Rajadhon. 1956. The Cultures of Thailand. Thailand: National Culture Institute.

Pongsripian, Vinai. 2008. Phannana Phum sathan Phranakhonsi-Ayutthaya:Ekkasan cak Ho Luang (Chabap khwam sombun) (Descriptions of Ayutthaya Landscape: A Document from Royal Hall (A Complete Edition). Bangkok: Usakhane. (In Thai).

Pride, William M., and O.C.Ferrell. 2016. Marketing. USA: Cengage Learning.

Prince Wan Waithayakon. 1944. “Thai Culture.” Journal of Siam Society 35 (2): 135-145.

Reid, Anthony. 1988. Southeast Asia in the Age of Commerce 1450-168o (Volume One: The Lands below the Winds). USA: Edwards Brothers.

Samattiya, Thanyarat. 2002. "The Importance of Indo-Pacific Chub Mackerel on Thai Society and Economy, 1854-1953." MA thesis, Thammasat University.

Sapienza, Irene, et al. 2010. "Effects of Basic Human Values on Host Community Acculturation Orientations." International Journal of Psychology 45 (4): 311-319.

Sujachaya, Sukanya. 2018a. Siamese Traditional Cuisine in the Ayutthaya Period. In Thai Gastonomy: From Home Kitchen to Royal Cuisine, edited by Sukanya Sujachaya, 137-165. Bangkok: Samlada.

Sujachaya, Sukanya. 2018b. Early Rattanakosin Recipes: The Integration of Ethnic Culinary Cultures in the Royal Court. In Thai Gastronomy: From Home Kitchen to Royal Cuisine, edited by Sukanya Sujachaya, 167-220. Bangkok: Samlada.

Tellström, Richard, Inga-Britt Gustafsson, and Lenai Mossberg. 20o6. "Consuming Heritage: The Use of Local Food Culture in Branding." Place Branding 2 (2): 130-143.

Tseng, Vivian, and Hirokazu Yoshikawa. 2008. "Reconceptualizing Acculturation: Ecological Processes, Historical Contexts, and Power Inequities." American Journal of Community Psychology 42 (3-4): 355.

Vallibhotama, Srisakra. 2011. Phatthanakan thang Sangkhom lae Watthanatham Thai (Thai Socio-cultural Development). Bangkok: Muang Boran. (In Thai).

Vargas, Persephone, and Leo-Felix Jurado. 2016. "Dietary Acculturation among Filipino Americans." International Journal of Environmental Research \& Public Health 13 (1): 16-26.

Watanasin, Ratiwan. 2012. Thai Food: "A Gateway of Cultural Understanding." Journal of Royal Institute of Thailand 4 (December): 145-164.

Wongwongsi, Sumon. 2014. Can Aroi cak Pu Ya: Sut Boran 100 Pi (Flavorful Dishes from Grandparents: 100 year-old Recipes). Bangkok: Sarakadee. (In Thai). 